\title{
Estimation of changes of vegetation cover in Sundarban using multi-temporal satellite data
}

\author{
Krishan Kundu ${ }^{1 *}$, Prasun Halder ${ }^{2}$, Jyotsna Kumar Mandal ${ }^{3}$ \\ ${ }^{1}$ Department of Computer Science and Engineering, Govt. College of Engineering \& Textile Technology, Serampore, India \\ ${ }^{2}$ Department of Computer Science and Engineering, Ram Krishna Mahato Government Engineering College, Purulia, West \\ Bengal, India \\ ${ }^{3}$ Department of Computer Science and Engineering, University of Kalyani, Kalyani, Nadia, West Bengal, India
}

Corresponding Author Email: krishan_cse@rediffmail.com

https://doi.org/10.18280/ama_d.230104

Received: 22 August 2018

Accepted: 16 November 2018

\section{Keywords:}

vegetation cover, sundarban, NDVI, satellite data, change detection

\begin{abstract}
Present study focuses the changes of vegetation cover (mangroves in forest region) in Sundarban during 2005 to 2015 based on the normalized difference vegetation index (NDVI). Seven vulnerable islands also reviewed which are positioned on the edge of south surface of Sundarban. The current survey reveals that approximately $1.07 \%$ vegetation area has been reduced during the period 2005-2010 and that of about 1.88\% during 20102015. From the inspection of seven islands, it is seen that most of the islands are eroded more than $15 \%$ on the south region of the Sundarban because of submerging due to rising sea level. About 2.95\% net vegetation area has been decreased during 2005 to 2015. This affect directly or indirectly on the normal biodiversity in Sundarban. It may also be inferred that the rate of depletion may be increased further in future. Therefore the study focuses to draw proper attention on extensive monitoring and managing the situation by arranging improvement of area of mangrove plantation.
\end{abstract}

\section{INTRODUCTION}

Vegetations are the essential asset in the world. It does create a natural barrier to guard along the riverbank and inland areas from normal disasters (hurricanes, tsunamis and cyclones) [1-3]. Its plays a vital role in ecological system such as soil preservation, increased biodiversity and preclusion of climate change. It is also produced growth of economic through provide such as timber of industry, construction and source of medicine. Sundarban is the solitary biggest tidal halophytic mangrove forests in the world. It is enclosed by Hooghly River on the west, on the east Ichamati-Kalindi-Raimangal, on the south Bay of Bengal, and on the north Dampier Hodge line. Three main River Ganga, Brahmaputra and Meghna assemble the Bay of Bengal along the India and Bangladesh, intertidal zone with wrapping an area approximately $10,000 \mathrm{~km}^{2}$ [4]. Among these areas India occupies by $40 \%$ of the net area and remaining area occupy by Bangladesh. Out of 102 islands in Sundarban region, 48 islands are reserved for forest and remaining island for the human settlement. It was also declared as biosphere reserve in 1989 by United Nations Educational and Scientific Co-operation (UNESCO) and world heritage site in 1987 by International Union for Conservation of Nature (IUCN).

Mangrove forests were declined in many regions of the world. During 1970 to 1990 mangrove forests areas were increased by $1.4 \%$ but mangrove forests were decreased by $2.5 \%$ during 1990 to 2000 [5] in Sundarban region (India and Bangladesh). During 1975 to 2006, approximately 0.42\% [6] mangrove areas are lost. In south Asia total mangrove forests were more deforested than the reforested between the year 2000 to 2012 [7]. Green parts of the vegetation area are more reflected in near infrared (NIR) band, but in red band that are more absorbs. Normalized difference vegetation index (NDVI) are used to evaluate the density of vegetation cover areas in a plant [8]. An extraction of data or information from multispectral image has been done using difference software. To explicit the dissimilarity characteristics of the mangroves species various classification techniques are used. Among these techniques on screen classification technique is superior to the others [9]. In compared with the various classification techniques the band ratio supervised classification is better [10] with respect to the accuracy. In recent last few years temperature is increasing in the environment [11-12]. Climate change also plays key role in changes of natural biodiversity of the environment. The changes of climate directly or indirectly impact on Sundarban estuary along the river bank or shoreline. Rising sea level, increased downstream salinity, increased the occurrence of cyclones in Bay of Bengal throughout the late monsoon, shoreline changes $[16,18]$, changes in biological and social features [13-15] of the area. In recently study the status and circulation of disparity of mangrove species were discussed Mitra et al. [17]. From these studies it was also seen that the mangrove vegetation areas were declined. The key intention of this paper is to analysis the vegetation area during last ten years (2005-2015). To study the present status, circulation and changes of vegetation cover areas of the Sundarban has also been emphasized. Besides, study the seven vulnerable islands on the edges of Sundarban. From the observation, it may be concluded that most of the islands were eroded on the south surface of Sundarban due to growing sea level and inundation. 


\section{STUDY AREA}

The present study area is located in the district of South 24 Paraganas at West Bengal state which shown in figure 1 . The areas are enclosed by reserve forest with several flora and fauna. In this region many species are exists such as mangroves, reptiles, mammals and birds. Wildlife species includes Indian python, man-eating Royal Bengal tiger, sharks, spotted deer, crocodiles, macaque monkey and wild boar are found in this region. Three major mangrove species such as Sundri, Goran and Gewa are plays an important role in vegetations indices. Other species also exists like Avicenia, Xylocarpus, Sonneratia, Bruguiera, Rhizophora and Nypa palm, etc. The study areas hold numerous deltaic islands enclosed by mangrove forest with total area of 303823.98 ha. The area surrounded by Bay of Bengal on the south, on the east border line of India and Bangladesh, on the west Thakuran River and on the north Basanti block. It includes various islands' such as Gana, Baghmara, Bhangaduni, Mayadwip, Chandkhali, Harinbangha, and Holiday Island. It is habitually flooded by diurnal tides.

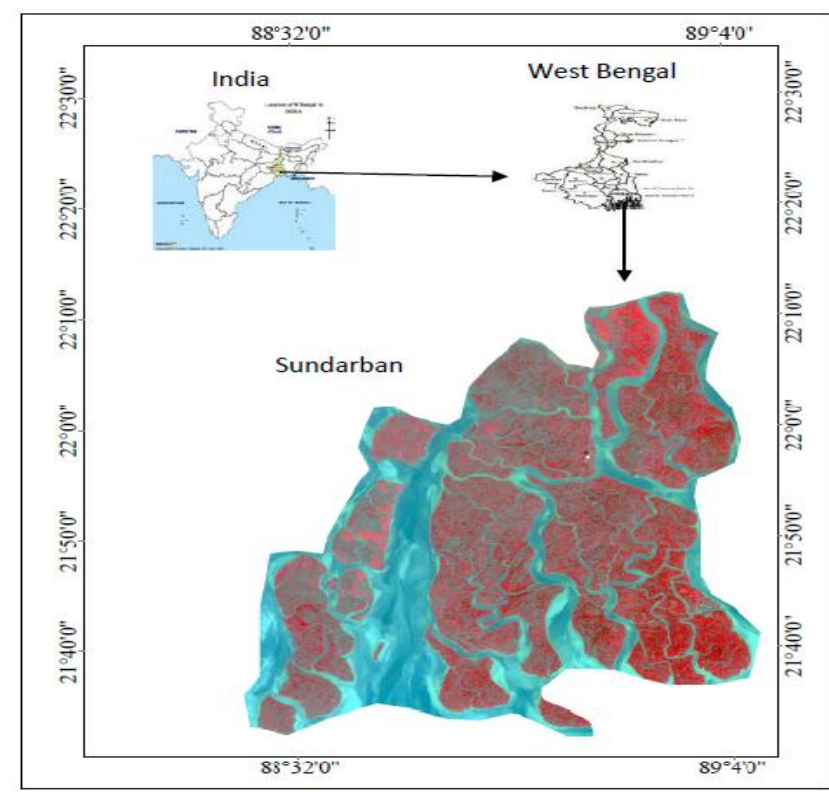

Figure 1. Geographical location of study area

\section{DATA AND METHODOLOGY}

\subsection{Data source}

In this article, remotely sensed data were collected from web such as united state geological survey (USGS) (http://glovis.usgs.gov/), global land cover facility (GLCF) (http://glcfapp.glcf.umd.edu/) and earth explorer (http://earthexplorer.usgs.gov/). Three years landsat enhanced thematic mapper plus (ETM+) images such as 2005 (Path 138, Row 45; dated 18 November 2005), 2010 (Path 138, Row 45; dated 20 December 2010) and 2015 (Path 138, Row 45; dated 13 November 2015) are help to carry out the present work. All the images were acquired almost in the same season and cloud free and clear with spatial resolution was $30 \mathrm{~m}$. A topographic map (79 C/9) with scale of 1:50,000 were obtained from Survey of India (SOI) which used for geo-referencing purpose.

\subsection{Image preprocessing}

Three landsat ETM+ images were preprocessed to extract and evaluate the important information from remotely sensed data. Image preprocessing operations were performed by TNTmips Professional 2015 software. The root means square error (RMSE) of less than $50 \mathrm{~m}$ is obtained during georeferencing for better accuracy. ETM+ multispectral sensor contains three bands such as green, red, near infrared (band 2, 3 and 4) are used for extracting the various features and among these bands near infrared band is more sensitive to forest land cover. The images are projected UTM with zone $45 \mathrm{~N}$ and WGS 84 datum. Image calibration, geometrical distortion and atmospheric correction were done by image processing software.

\subsection{Normalized difference vegetation index (NDVI)}

Various materials are existing on the earth surface. The earth materials are vegetation, soil, water, bare rock, etc. Using spectral reflectance signature any material can be recognized. The spectral reflectance value is different for the various materials because their characteristic also difference. Fresh/ Shallow water reflectance value is low. The reflectance value is high at the end of blue band of the spectrum and decreases as wavelength increases. Hence, fresh water visible dark-bluish. Turbid water contains various sediment suspensions which increase the reflectance in the red end of the spectrum and it does appear as brownish. The reflectance of bare land depends on its composition. Normalized difference vegetation index (NDVI) is the one of the major important vegetation index among all these indices. It finds out the thickness of the green on an area of land. During photosynthesis process the green part of the chlorophyll of vegetation robustly absorbs visible light (from $400 \mathrm{~nm}$ to $700 \mathrm{~nm}$ ). But in other side strongly reflects near infrared band (from $700 \mathrm{~nm}$ to $1100 \mathrm{~nm}$ ). The main purpose of NDVI is that the rate of reflection differs for the band 4 near infrared (NIR) and band 3 (Red) of an image and thus these variations can generate an image which signifies the status of green vegetations and is least influenced by topography. The NDVI value is calculated using the following equation:

$\mathrm{NDVI}=\frac{\mathrm{NIR}-\mathrm{RED}}{\mathrm{NIR}+\mathrm{RED}}$

In general NDVI values range from -1 to +1 . Extremely negative value indicates the water body due to its spectral reflectance value is negative low. Positive value indicates the vegetation cover area and its spectral reflectance value is high. Towards the +1 value indicates the dense vegetation area and its spectral reflectance value very high. Beginning of the positive value indicates that the open vegetation area and its reflectance value low but positive. Beyond 0.5 represent the moderate vegetation area and its reflectance value is between the low and high. In this study entire land cover areas were separated into five classes according to the values of NDVI. The values range from -1 to -0.07134 are considered as shallow water, values range from -0.07133 to 0 are considered as turbid water, values range from 0.00001 to 0.18492 are considered as open mangrove area, values range from 0.18493 to 0.34304 are considered as moderate mangrove area, values range from 0.34305 to +1 are represent the dense mangrove area. 


\subsection{Proposed methodology}

After preprocessing of three landsat ETM+ image, a layer stacking tool is used to combine three bands (bands 2, 3 and 4 for ETM+) into a single layer and create a false color combination (FCC) and then crop the study area. To obtain the NDVI values, two bands (red band, NIR band) are opened and select the equation (1). Then select the scale factor with 1 . The results of NDVI values are ranges from -1 to +1 and spitted into five categories such as -1 to -0.07134 , 0.07133 to $0,0.00001$ to $0.18492,0.18493$ to 0.34304 and 0.34305 to +1 . Different colors are assigned for these five categories NDVI values. For the study of seven vulnerable islands, three year images of 2005, 2010 and 2015 are digitized followed by estimated and analyzed of each island areas. Figure 2 depict the methodology of the present work.

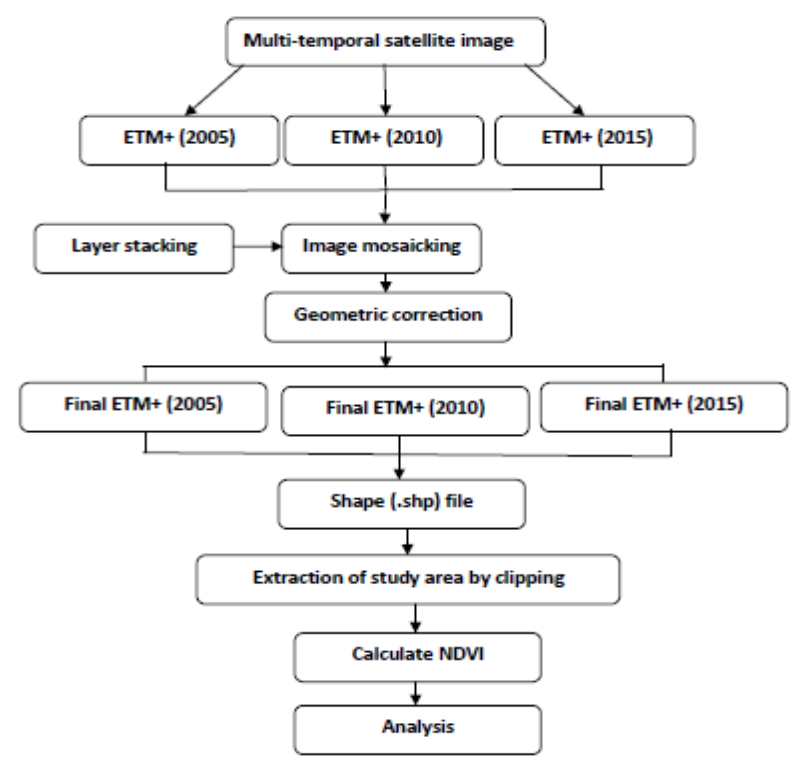

Figure 2. Methodology for study area

\section{RESULTS AND DISCUSSIONS}

According to the values of NDVI the present study area was divided into five classes (shallow/fresh water, turbid water, open mangrove area, moderate mangrove area and dense mangrove area). Figure 5 represents the NDVI values calculated from the image of 2005, 2010 and 2015. Each class represents unique colors. Table 1 illustrates that in 2005 fresh/shallow water was $31.87 \%$ (96828.70 ha), in 2010 it was slightly increased to $32.17 \%$ (97740.17 ha), while in 2015 it has been severely decreased to $24.20 \%$ ( 73525.40 ha). In 2005 , turbid water was $3.88 \%$ (11788.37 ha), in 2010 it was marginally increased to $4.65 \%$ (14127.82 ha), but in 2015 it has been significantly increased to $14.50 \%$ (44054.48 ha). In 2005, total open mangrove area was $11.32 \%$ (34392.87 ha), which marginally increased to $12.23 \%$ (37157.67 ha) in 2010, but in 2015 slightly decreased to $10.50 \%$ (31901.52 ha). In 2005 total moderate mangrove area was $14.75 \%$ (44814.04 ha), which rapidly increased to $19.75 \%$ (60005.24 ha) in 2010, in 2015 progressively increased to $21.30 \%$ (64714.51 ha). In 2005 net dense mangrove area was $38.38 \%$ (116000.00 ha), which radically decreased to $31.20 \%$
(94793.08 ha) in 2010, in turn which has also significantly decreased to $29.50 \%$ ( 89628.07 ha).

Table 2 depicts the land cover class areas were changes and percentage of areas changes during 2005 to 2010, 2010 to 2015 , and 2005 to 2015 . From the analysis of the table, it is reveals that shallow/fresh water was slightly increased by $0.30 \%$ during 2005 to 2010 whereas from year 2010 to 2015 shallow/fresh water rapidly decreased by about $7.97 \%$. Therefore, overall $7.67 \%$ (2330.3 ha) shallow/turbid water has been decreased from 2005 to 2015 due to frequent natural distruster (cyclones, storms, tsunamis etc) in the region of Sundarban. As a result fresh/shallow water has been declined, but turbid water has been increased by $10.62 \%$ from 2005 to 2015. Most of the turbid water is seen in small channel in the forest region which is shown in fig 3. Vegetation areas were classified into three categories like open vegetation area, moderate vegetation area, and dense area. Open vegetation areas were increased about $0.91 \%$ along the riverbank during 2005 to 2010 because of initiation of plantation programs, while during 2010 to 2015 open mangrove areas were decreased by $1.73 \%$ approximately due to increase of about $10.62 \%$ turbid water. Overall, open vegetation areas were slightly declined by $0.82 \%$ during 2005 to 2015. Open mangrove areas are situated on the West/West-North Sundarban. During 2005 to 2010 moderate vegetation areas about 5\% are increased and the same are progressively increased about $1.55 \%$ during 2010 to 2015 due to growth of vegetation. Moderate vegetation areas are increased approximately by $6.55 \%$ during 2005 to 2015 . During 2005 to 2010 , dense vegetation areas are depleted by about $6.98 \%$ which is further declined by about $1.70 \%$ during 2010-2015. The net dense vegetation areas were declined by an amount of $8.68 \%$ during 2005 to 2015 because of erosion along the sea surface. Dense mangrove area is observed on the south, South-East and East side of Sundarban. From the study it is revealed that overall vegetation areas were decreased by $2.95 \%$ during 2005 to 2015 . Vegetation areas were gradually decreasing due to changes of natural atmosphere, global warning, rising sea level, frequently occurs in rainstorm in the region of island and others natural effects. Figure 3 shows the land cover class wise area in 2005, 2010 and 2015. Year wise vegetation areas are shown in figure 4. It is seen from these figures that open mangrove areas and dense mangrove areas were both gradually decreasing, while moderate mangrove areas were gradually increasing. Figure 6 clearly indicates that entire vegetation areas were gradually decreasing during 2005 to 2015 .

Various susceptible islands such as Bhangaduni, Bulchery, Mayadwip, Mechua, Gona, Chulkati, Haliday Island are shown in figure 8 and their areas are represented by table 3 . All these islands are situated on the southern region of Sundarban. These regions are more eroded during 2005-2015. In Bhangaduni island (shown in figure 7(a)) the original areas in 2005 was $16.39 \mathrm{~km}^{2}$ which slightly decreased to $16.3 \mathrm{~km}^{2}$ in 2010 and continued in depleting to $10.45 \mathrm{~km}^{2}$ in 2015 . This is an inaccessible island and its erosion rate is very high (36.34\% during 2005 to 2010). From the figure, it is clear that most of the erosion was done on the edge of south, south-east and north-east face of this island because of rising sea level. The Bulchery island is located at the edge of Sundarban and Thakuran River is in its west and Matla River is on the east. In 2005 overall land cover area was $25.7 \mathrm{~km}^{2}$, which is slightly decreased to $23.49 \mathrm{~km}^{2}$ in 2010 and progressively decreased to $21.41 \mathrm{~km}^{2}$ as seen from the image 
of 2015. During 2005 to 2015, net $16.69 \%$ areas are lost approximately. Figure 7(b) shows that major erosion was done on the east, west and the south position of this island caused by high pressure of water level. The Mayadwip Island is shown in figure 7(c) which situated on the east of Matla River. In this island the major erosion occurs on the surface of west and south. In 2005 net area was $66.99 \mathrm{~km}^{2}$, which decreased to $65.92 \mathrm{~km}^{2}$ in 2010 , progressively decreased with to $61.01 \mathrm{~km}^{2}$ in 2015. During 2005 to 2015 total erosion $(8.93 \%)$ were observed because of rising sea level and floods. The Mechua Island is also located on the edge of the Sundarban. Major erosion was observed on the South surface of this island which is shown in figure $7(d) .5 .12 \%$ of total land cover percentage of areas was lost during 2005 to 2015. In the Gona island land cover area was lost approximately by
$2.52 \%$ during 2005 to 2015 which is shown in figure 7(e). $7.71 \%$ of the land cover area of Chulkati Island was lost during 2005 to 2015 which is shown in figure 7(f). The Haliday island is the most of the eroded island. Percentage of area lost is $84.21 \%$, which is shown in figure $7(\mathrm{~g})$. Figure 7 shows the graphical representation of the various islands with their areas. From these observations, it is clear that all the islands land cover areas were declined during 2005 to 2015 due to high pressure of the sea level water and most eroded island is Haliday island. It is also scrutinized that major erosion occurs on the south surface of each island due to increase sea level and submerges. Moreover, it has also examined that in the shoreline along the river bank of the island dense vegetation areas were increased while in the middle of the island dense vegetation areas were declined.

Table 1. Land cover classes area (in ha) and percentage of area in 2005, 2010 and 2015

\begin{tabular}{|c|c|c|c|c|c|c|c|c|}
\hline \multicolumn{2}{|c|}{ NDVI Value } & \multirow{3}{*}{$\begin{array}{c}\text { Land } \\
\text { Cover } \\
\text { Class } \\
\text { Shallow } \\
\text { water }\end{array}$} & \multicolumn{2}{|c|}{ Year: 2005} & \multicolumn{2}{|c|}{ Year: 2010} & \multicolumn{2}{|c|}{ Year: 2015} \\
\hline \multirow{2}{*}{$\begin{array}{c}\text { From } \\
-1\end{array}$} & \multirow{2}{*}{$\begin{array}{c}\text { To } \\
-0.07134\end{array}$} & & \multicolumn{2}{|c|}{$\begin{array}{c}\text { Area of Area } \\
\text { (in ha) }\end{array}$} & \multicolumn{2}{|c|}{$\begin{array}{c}\text { Area of Area } \\
\text { (in ha) }\end{array}$} & \multicolumn{2}{|c|}{$\begin{array}{cc}\text { Area } & \begin{array}{c}\% \text { of Area } \\
\text { (in ha) }\end{array} \\
\end{array}$} \\
\hline & & & 96828.70 & $31.87 \%$ & 97740.17 & $32.17 \%$ & 73525.40 & $24.20 \%$ \\
\hline$-\mathbf{0 . 0 7 1 3 3}$ & 0 & $\begin{array}{l}\text { Turbid } \\
\text { water }\end{array}$ & 11788.37 & $3.88 \%$ & 14127.82 & $4.65 \%$ & 44054.48 & $14.50 \%$ \\
\hline 0.00001 & 0.18492 & $\begin{array}{c}\text { Open } \\
\text { Vegetation }\end{array}$ & 34392.87 & $11.32 \%$ & 37157.67 & $12.23 \%$ & 31901.52 & $10.50 \%$ \\
\hline 0.18493 & 0.34304 & $\begin{array}{l}\text { Moderate } \\
\text { Vegetation }\end{array}$ & 44814.04 & $14.75 \%$ & 60005.24 & $19.75 \%$ & 64714.51 & $21.30 \%$ \\
\hline 0.34305 & +1 & $\begin{array}{c}\text { Dense } \\
\text { Vegetation }\end{array}$ & 116000.00 & $38.18 \%$ & 94793.08 & $31.20 \%$ & 89628.07 & $29.50 \%$ \\
\hline
\end{tabular}

Table 2. Land cover classes area changes (in ha) and percentage of changes of 2005-2010, 2010-2015 and 20052015

\begin{tabular}{ccccccc}
\hline $\begin{array}{c}\text { Land Cover } \\
\text { Class }\end{array}$ & \multicolumn{2}{c}{$\mathbf{2 0 0 5 - 2 0 1 0}$} & \multicolumn{2}{c}{$\mathbf{2 0 1 0}-\mathbf{- 2 0 1 5}$} & \multicolumn{2}{c}{$\mathbf{2 0 0 5 - 2 0 1 5}$} \\
(in ha) & \% of Change & (in ha) & \% of Change & (in ha) & \% of Change \\
\hline $\begin{array}{c}\text { Shallow Water } \\
\text { Turbid Water }\end{array}$ & +911.47 & $+0.30 \%$ & -24214.77 & $-7.97 \%$ & -23303.3 & $-7.67 \%$ \\
$\begin{array}{c}\text { Open Vegetation } \\
\text { Moderate }\end{array}$ & +2339.45 & $+0.77 \%$ & +29926.66 & $+9.85 \%$ & +32266.11 & $+10.62 \%$ \\
$\begin{array}{c}\text { Vegetation } \\
\text { Dense }\end{array}$ & +15191.2 & $+5.00 \%$ & +4709.27 & $+1.55 \%$ & +19900.47 & $+6.55 \%$ \\
Vegetation & -21206.92 & $-6.98 \%$ & -5165.01 & $-1.70 \%$ & -26371.93 & $-8.68 \%$ \\
\hline
\end{tabular}

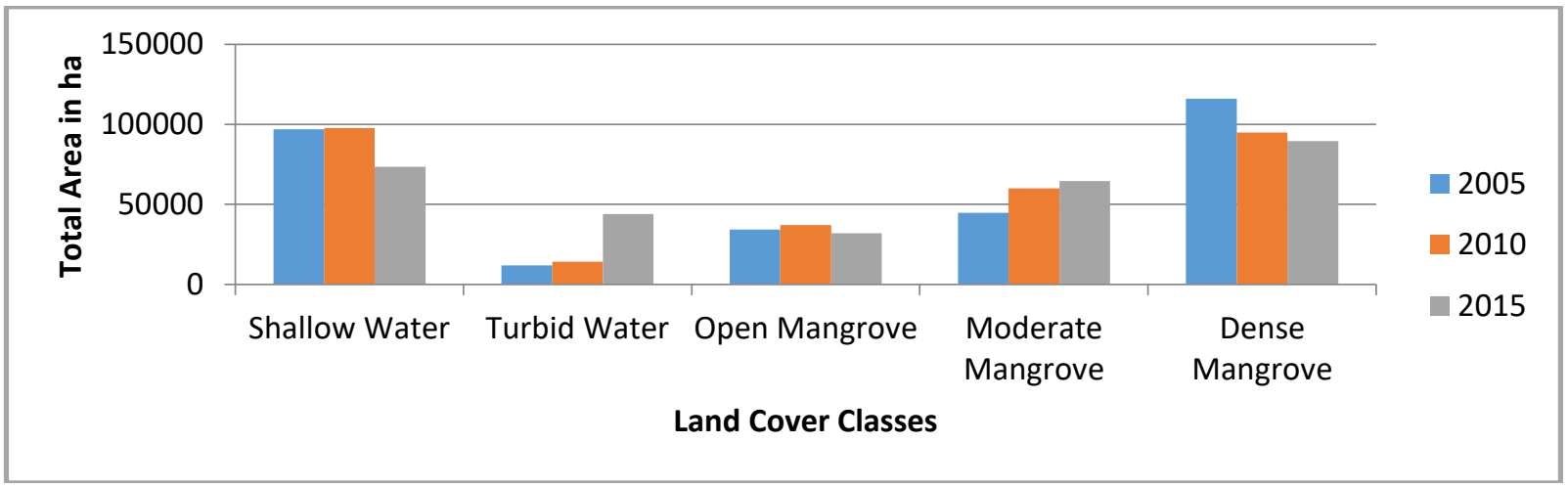

Figure 3. Land covers class-wise area 


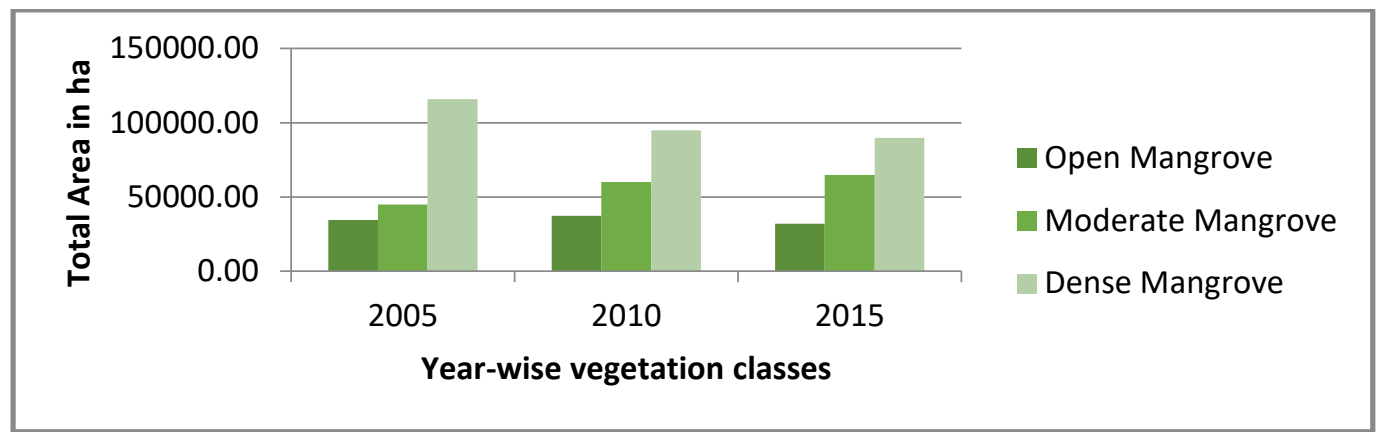

Figure 4. Year-wise different vegetation areas
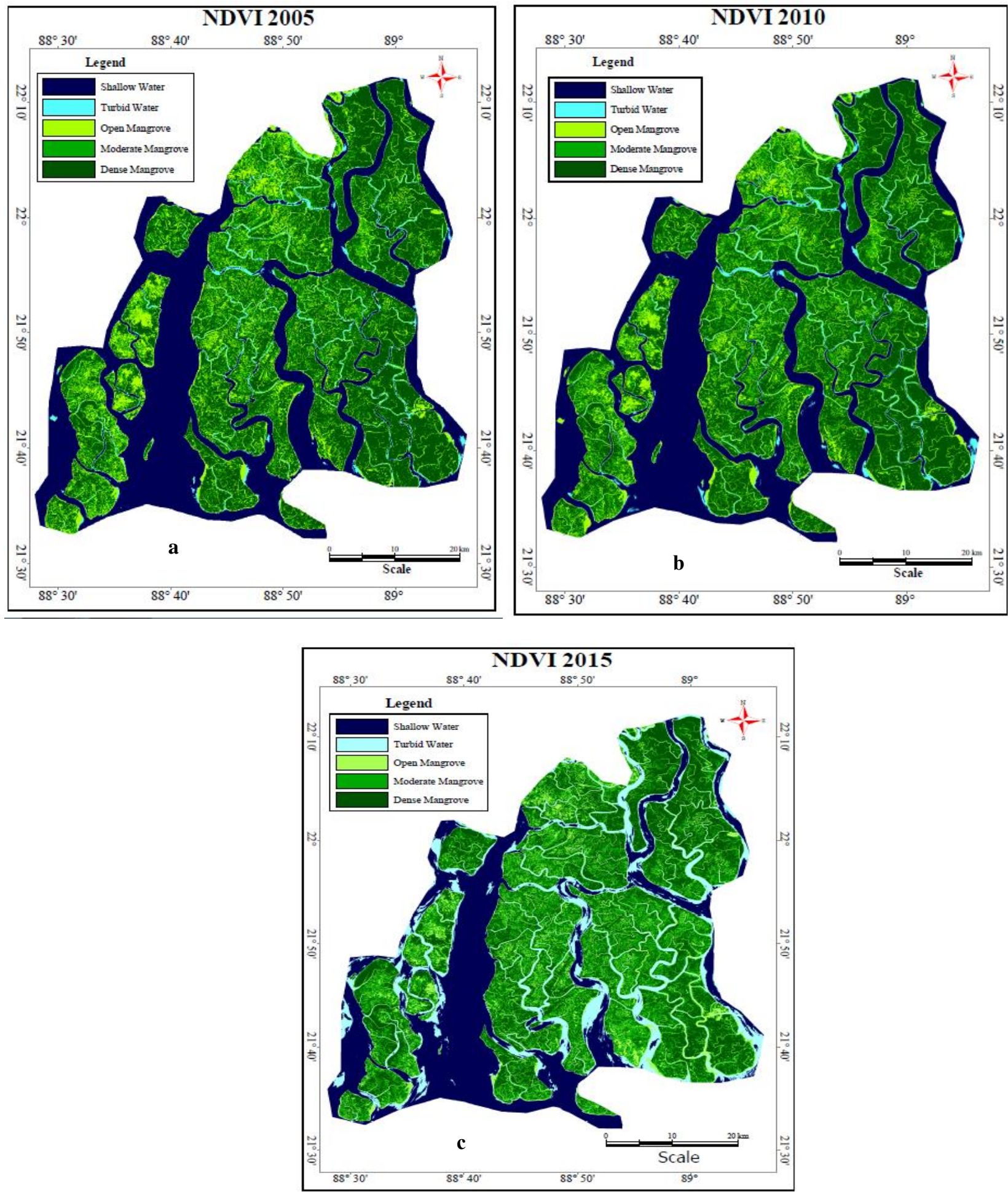

Figure 5. NDVI value of 2005 (a), 2010 (b), 2015 (c) 


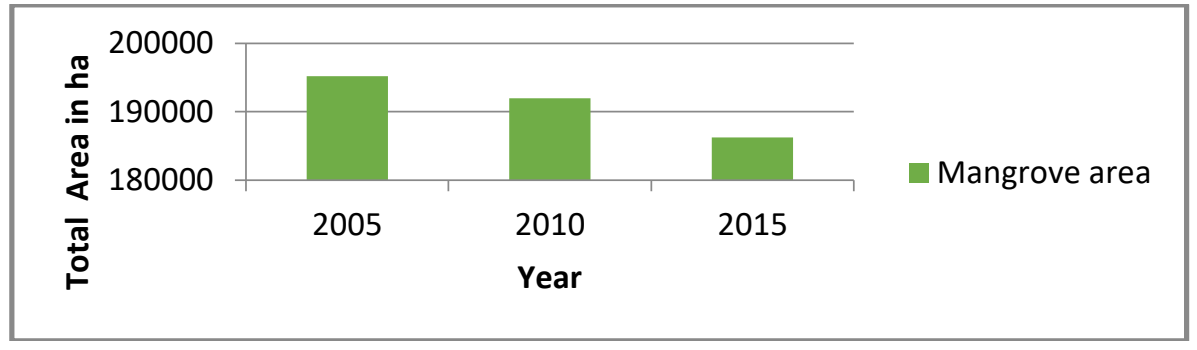

Figure 6. Year-wise vegetation areas

Table 3. Islands with their areas in 2005, 2010 and 2015 (in $\mathrm{km}^{2}$ )

\begin{tabular}{ccccccc}
\hline Island & $\mathbf{2 0 0 5}$ & $\mathbf{2 0 1 0}$ & $\mathbf{2 0 1 5}$ & $\begin{array}{c}\text { Net loss/gain } \\
\mathbf{2 0 0 5 - 2 0 1 0}\end{array}$ & $\begin{array}{c}\text { Net loss/gain } \\
\mathbf{2 0 0 5 - 2 0 1 5}\end{array}$ & $\begin{array}{c}\text { Net \% of loss } \\
\mathbf{2 0 0 5 - 2 0 1 5}\end{array}$ \\
\hline Bhangaduni & 16.39 & 16.3 & 10.45 & -0.09 & -5.94 & 36.24 \\
Bulchery & 25.7 & 23.49 & 21.41 & -2.21 & -4.29 & 16.69 \\
Mayadwip & 66.99 & 65.92 & 61.01 & -1.07 & -5.98 & 8.93 \\
Mechua & 18.59 & 17.91 & 17.63 & -0.68 & -0.96 & 5.16 \\
Gona & 50.43 & 50.19 & 49.16 & -0.24 & -1.27 & 2.52 \\
Chulkati & 40.87 & 40.56 & 37.72 & -0.31 & -3.15 & 7.71 \\
Haliday & 1.9 & 1.3 & 0.3 & -0.6 & -1.6 & 84.21 \\
\hline
\end{tabular}

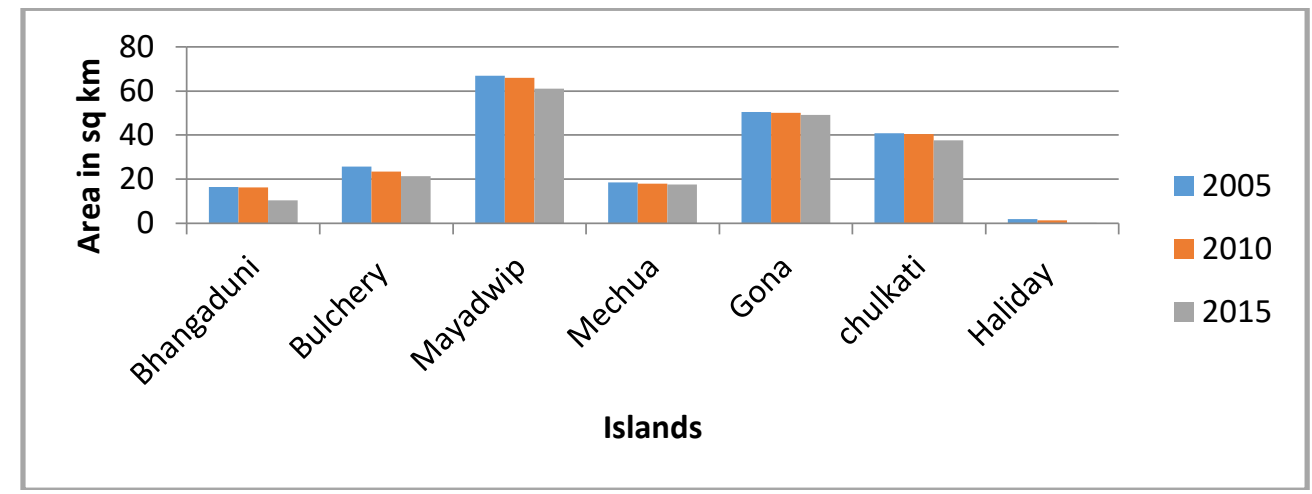

Figure 7. Islands areas

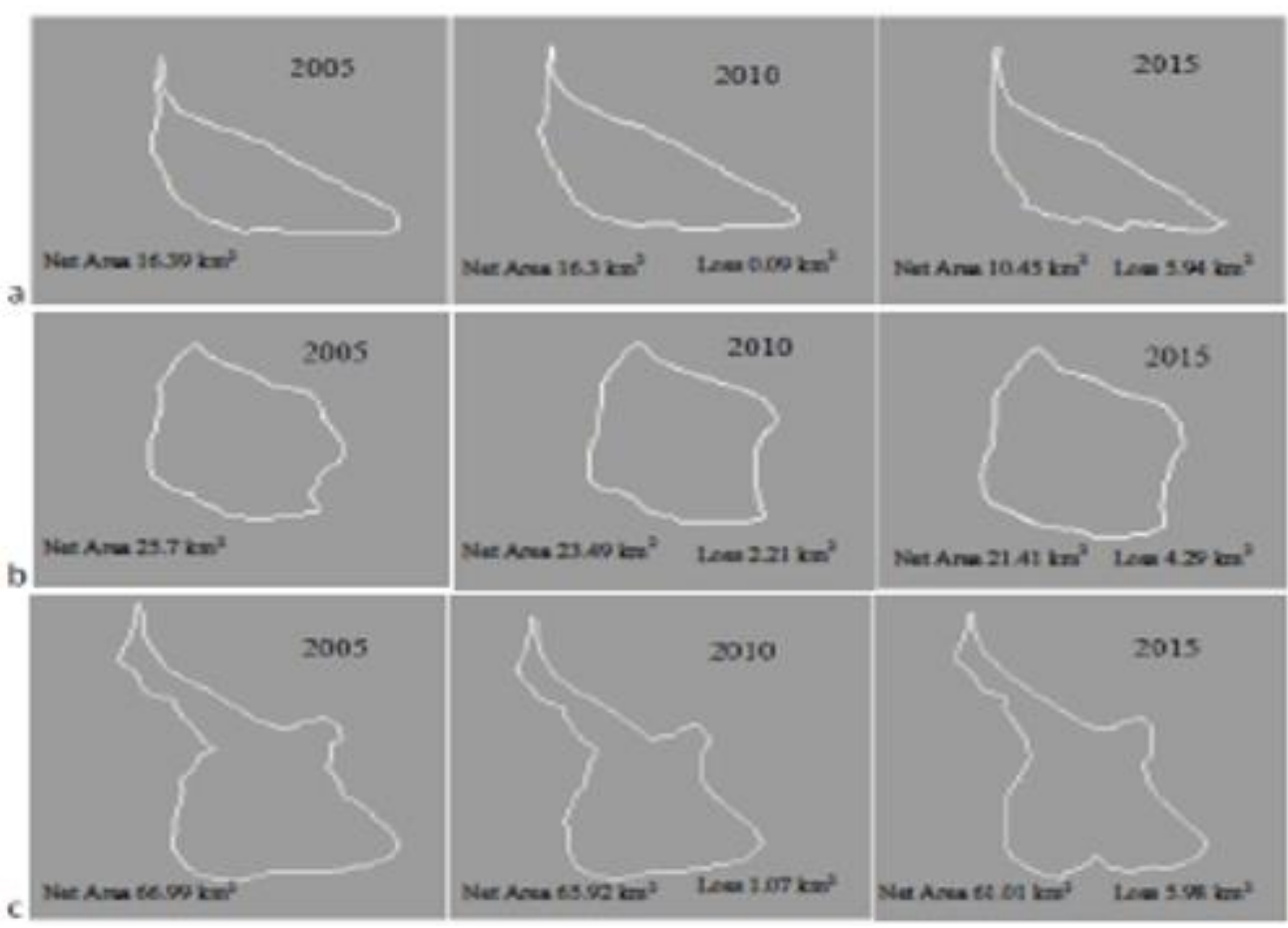




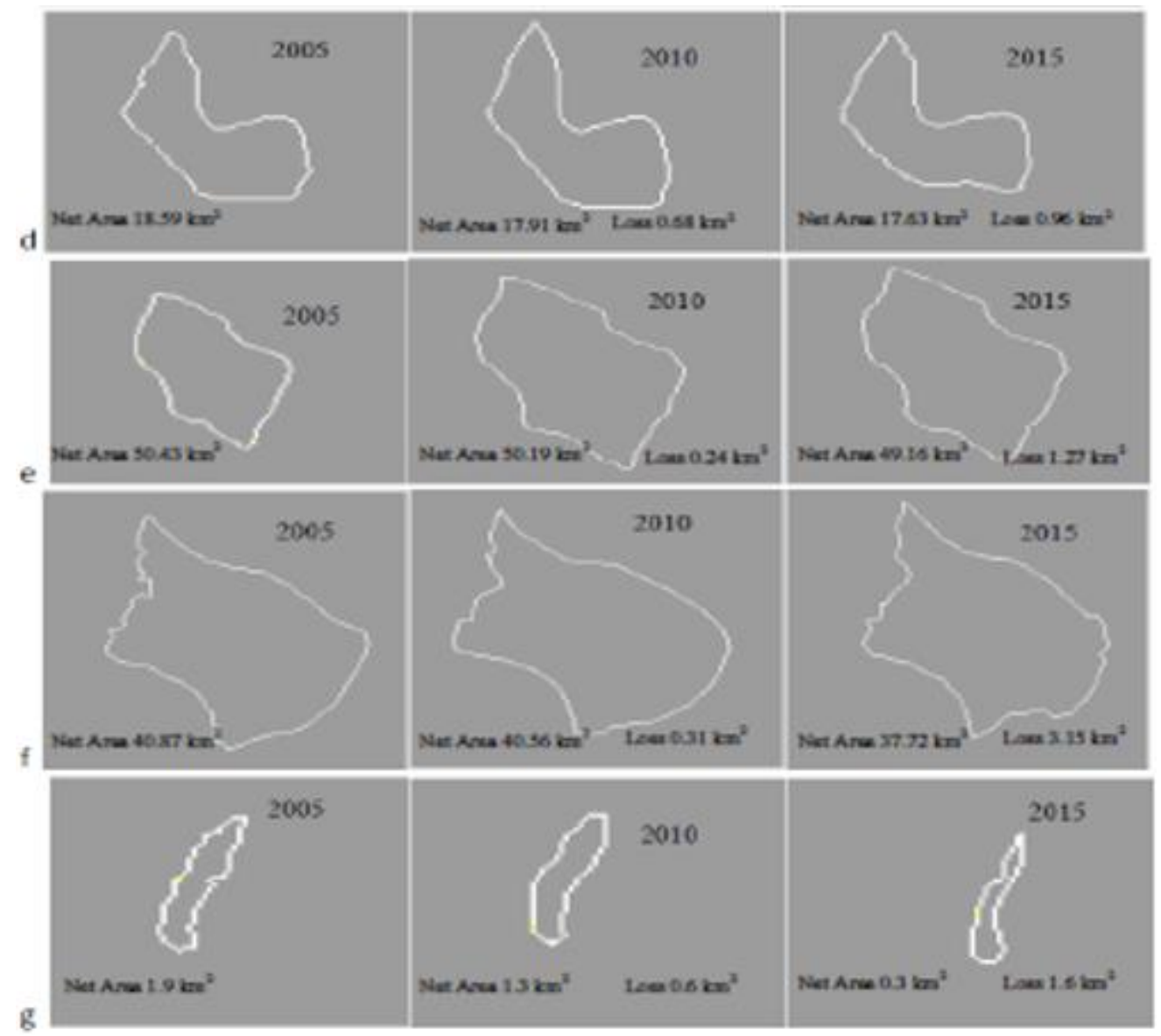

Figure 8. Digitization of shoreline a. Bhangaduni b. Bulchery Island c. Mayadwip d. Mechua e. Gona f. Chulkati g. Haliday island

\section{CONCLUSIONS}

In the present study, it is reveals that Sundarban, vegetation area was gradually decreased during 2005 to 2015 due to changes of natural atmosphere, global warning, rising sea level, floods, pollutions, fall in fresh water availability, overharvesting, coastal erosion, decline of sediment deposition, often occurs in cyclones and hurricanes. On the other hand, vegetation areas are increased because of aggradation, plantation and growth of plantation. During 2005 to 2010 vegetation areas were decreased by about $1.07 \%$ (-3250.92 ha) and during 2010 to 2015 further declined by about $1.88 \%$ (-5711.89 ha). Therefore, overall vegetation areas are continuously declined by about $2.95 \%$. From two observations (2005-2010, 2010-2015), it has been seen that in 2010-2015, vegetation cover areas declined rate almost double in compared with the 2005-2010 and gradual trends of declination also observed. Although these changes were not significant in the perspective of error associated because during collection of image natural environmental condition was not same. Among seven vulnerable islands, it has been observes that major erosion process were done on the South surface of each islands due to high pressure of the water level. The study also examined that during 2005 to 2015 highest eroded island is Haliday with an erosion rate $84.21 \%$, followed by Bhangaduni island (36.24\%), Bulcherry island (16.69\%) and so on. Mangrove deforestation were observed on intertidal zone of the islands reasons of illegal cutting trees, etc while mangrove regeneration occurs on the shoreline or along the riverbank caused by new plantation programme, regrowth and aggradation. In future, it may be suspect that in the year of 2030 vegetation area may be depleted by approximately $6 \%$ of net vegetation area in comparison with the data in 2005 because of increasing global warning over the globe. Therefore, monitoring, maintaining and controlling the mangrove areas are urgently needed to survive the natural coastal ecosystem in Sundarban.

\section{REFERENCES}

[1] Alongi DM. (2008). Mangrove forests: Resilience; protection from tsunamis; and responses to global climate change. Estuar. Coast. Shelf Sci. 76: 1-13.

[2] Fromard F, Vega C, Proisy C. (2004). Half a century of dynamic coastal change affecting mangrove shorelines of French Guiana. A case study based on remote sensing data analyses and field surveys. Marine Geology 208: 265-280.

[3] Cochard R, Ranamukhaarachchi SL, Shivakoti GP, Shipin OV, Edwards PJ, Seeland KT. (2008). The 2004 tsunami in Aceh and Southern Thailand: A review on coastal ecosystems; wave hazards and vulnerability. Perspect. Plant Ecol. Evol. Systemat. 10: 3-40.

[4] Ghosh A, Schmidt S, Fickert T, Nüsser M. (2015). The Indian Sundarban Mangrove Forests: History, utilization, conservation strategies and local perception. Diversity 7: 149-169.

[5] Giri C, Pengra B, Zhu Z, Singh A, Tieszen LL. (2007a). Monitoring mangrove forest dynamics of the 
Sundarbans in Bangladesh and India using multitemporal satellite data from 1973 to 2000. Estuarine, Coastal and Shelf Science 73: 91-100.

[6] Datta D, Deb S. (2012). Analysis of coastal land use/land cover changes in the Indian Sunderbans using remotely sensed data. Geo-spatial Information Science 15: 241-250.

[7] Giri C, Long J, Abbas S, Murali R, Qamer FM, Pengra B, Thau D. (2014). Distribution and dynamics of mangrove forests of South Asia. Journal of Environmental Management 148: 1-11.

[8] Morawitz DF, Blewett TM, Cohen A. (2006). Using NDVI to assess vegetative land cover change in central puget sound. Environ. Monit. Assess 114(1-3): 85-106.

[9] Nandy S, Kushwaha SPS. (2011). Study on the utility of IRS 1D LISS-III data and the classification techniques for mapping of Sunderban mangroves. J. Coast. Conserv. 15: 123-137.

[10] Rahman MM, Ullah M, Lan M, Sumantyo JT, Kuze H, Tateishi R. (2013). Comparison of Landsat image classification methods for detecting mangrove forests in Sundarbans. Int. J. Remote Sens. 34: 1041-1056.

[11] Raha AK, Zaman S, Sengupta K, Bhattacharyya SB, Raha S, Banerjee K, Mitra A. (2013). Climate change and sustainable livelihood programme: A case study from Indian Sundarbans. J. Ecol. 107: 335-348.

[12] Raha A, Das S, Banerjee K, Mitra A. (2012). Climate change impacts on Indian Sunderbans: A time series analysis (1924-2008). Biodivers. Conserv. 21: 12891307.

[13] Unnikrishnan AS, Kumar MRR, Sindhu B. (2011). Tropical cyclones in the Bay of Bengal and extreme sea-level projections along the east coast of India in a future climate scenario. Curr. Sci. India 101: 327-331.

[14] Hazra S, Ghosh T, DasGupta R, Sen G. (2002). Sea level and associated changes in the Sundarbans. Sci. C. 68: 309-321.

[15] Nandy S, Bandopadhyay S. (2011). Trend of sea level change in the Hugli estuary, India. Indian J. Geo-Mar. Sci. 40: 802-812.

[16] Jayappa KS, Mitra D, Mishra AK. (2006). Coastal geomorphological and land-use and land cover study of Sagar Island, Bay of Bengal (India) using remotely sensed data. Int. J. Remote Sens. 27(17): 3671-3682.

[17] Mitra D, Karmekar S. (2010). Mangrove classification in sunderban using high resolution multi spectral remote sensing data and GIS. Asian J. Environ. Disast. Manage. 2(2): 197-207.

[18] Thomas JV, Arunachalam A, Jaiswal R, Diwakar PG, Kiran B. (2014). Dynamic land use and coastline changes in active estuarine regions - a study of sundarban delta, the international archives of the photogrammetry. Remote Sensing and Spatial Information Sciences, Volume XL-8, 2014 ISPRS Technical Commission VIII Symposium, Hyderabad, India. 